$\xi=-1$

\title{
Analysis of Heavy Metals in Pigments Used in Makeup Tattoo
}

\author{
Hui-Seong Lee ${ }^{1}$, Jung-SeungChoi ${ }^{2}$, Dae-JinBaek ${ }^{3}$, Mi-RaJeong ${ }^{4 *}$ \\ ${ }^{* 1,2,3}$ Dept. of Cosmetology \& Chemistry, Hanseo University, Seosan-si, Chungcheongnam-do, 31962, Korea \\ ${ }^{4}$ Dept. of Health Care, Hanseo University, Hanseo University, Seosan-si, Chungcheongnam-do, 31962, Korea \\ *Corresponding author E-mail: jlovemer@naver.com
}

\begin{abstract}
Background/Objectives: This study aims to provide basic material to establish safety sign standard and control standard of cosmetic tattoo pigment by analyzing heavy metal component of pigment used in cosmetic tattoo.

Methods/Statistical analysis: The experiment analyzed heavy metal such as antimony( $\mathrm{Sb}), \operatorname{cobalt}(\mathrm{Co}), \operatorname{copper}(\mathrm{Cu}), \mathrm{lead}(\mathrm{Pb}), \operatorname{zinc}(\mathrm{Zn})$, barium(Ba), tin(Sn) included in regulated item by applying safety standard of prohibition of use or content restriction of hazardous material since September 26, 2015 in accordance with "Act on Registration, Evaluation, Etc. of Chemical" simplemented by the Environment department on June 26, 2015.

Findings: As a result of examining the contents of heavy metals in dyes and pigments used in cosmetic tattoo products, it was found that the total of 5 products exceeded the reference value and found to be unsuitable for safety standards.

Improvements/Applications: it requires marking of detailed compound ingredient and guidelines. There is a need for micro content analysis using precise measuring tool in the future.
\end{abstract}

Keywords: Make up tattoo, Heavy metal, Pigment, Dye, Semi-permanent.

\section{Introduction}

The term tattoo which is originally came from Tahitian means staining face by injecting dye after making a hole on skin[1,2]. It was an ancient custom conducted since B.C 3000, but current cosmetic tattoo is conducted in wider range of purpose such as medical treatment for disguising trauma, surgical scar, burn, skin graft, hair loss, leukoplakia or body arts since Bettman started to tattoo on eyebrow and eyelid on patient without hair in 1920 and Louis Byars, a surgical doctor who started to tattoo scar and discolored skin in 1944. Also, cosmetic tattoo on eyelid, eyebrow, lip, hairline for aesthetic purpose is preferred by more consumers as it reduces makeup time, covers flaws on appearance, is waterproof and continues for several years [3].

Modern cosmetic pigment is mostly organic, but coloring pigment still contains heavy metal such as antimony, arsenic, cadmium, chrome, cobalt, lead and nickel [4,5]. Arsenic is a very toxic material which not only affect skin, lung, liver, bladder and kidney cancer negatively in case of chronic exposure, but also lead to death if exposed to high content [6,7]. Other words, exposure of heavy metal after receiving cosmetic tattoo could lead to side effects such as skin and local lymphatic gland, skin disease, skin discoloring, vomiting, herpes, headache or potential cancinogenesis $[5,8]$.

When performing cosmetic tattoo, about $1 \mathrm{mg}$ of pigment is injected per $1 \mathrm{~cm}^{2}$ of tattoo, and toxic heavy metal that is injected inside skin from pigment on scarf skin for one tattooing pose potential harm from several months to years with its chemical reaction. Recently, due to increased demand of cosmetic tattoo, side effect of pigment is also increasing which intrigued awareness about necessity of regulation for safety of pigment. Thus, Council of Europe has emphasized on necessity to accurately regulate cosmetics tattoo in 2003. Cosmetics regulation imposed by EU in 2008, regulation about pigment's toxicity control imposed by German BFR, designation as 'risk concerned product' in accordance with "Act on Registration, Evaluation, Etc. of Chemicals" in Korea on June 26, 2015 are examples of countries regulating safety standard of hazardous substance as law[4].

Thus, this study aims to provide basic material to establish safety sign standard and control standard of cosmetic tattoo pigment by analyzing heavy metal component of pigment used in cosmetic tattoo.

\section{Materials and Methods}

The experiment analyzed heavy metal such as antimony(Sb), cobalt $(\mathrm{Co})$, copper $(\mathrm{Cu})$, lead $(\mathrm{Pb})$, $\operatorname{zinc}(\mathrm{Zn})$, barium $(\mathrm{Ba}), \operatorname{tin}(\mathrm{Sn})$ included in regulated item by applying safety standard of prohibition of use or content restriction of hazardous material since September 26, 2015 in accordance with [Act on Registration, Evaluation, Etc. of Chemicals $\lrcorner$ implemented by the Environment department on June 26, 2015. [Table 1].

Table 1: Test method for analysis of metals

\begin{tabular}{|l|l|l|}
\hline Measuring metal & 1 & 2 \\
\hline $\mathrm{Sb}$ & $\mathrm{O}$ & $\mathrm{O}$ \\
\hline $\mathrm{Co}$ & $\mathrm{O}$ & $\mathrm{O}$ \\
\hline $\mathrm{Cu}$ & $\mathrm{O}$ & $\mathrm{O}$ \\
\hline $\mathrm{Pb}$ & $\mathrm{O}$ & $\mathrm{O}$ \\
\hline $\mathrm{Zn}$ & $\mathrm{O}$ & $\mathrm{O}$ \\
\hline $\mathrm{Ba}$ & $\mathrm{O}$ & $\mathrm{O}$ \\
\hline $\mathrm{Sn}$ & $\mathrm{O}$ & $\mathrm{O}$ \\
\hline
\end{tabular}


1. Inductively Coupled Plasma Atomic Emission Spectroscopy

2. Inductively Coupled Plasma Mass Spectrometry

\subsection{Experiment Sample}

This experiment randomly selected 5 products with self-check number that is one the market. Colors and numbers of sample are no. 40 brown, no. 41 dark brown, no. 42 black, no. 43 pink, and no. 44 [Table 2].

Table 2: Samples 40 to 44 colors

\begin{tabular}{|l|l|}
\hline Pigment Number & Pigment color \\
\hline P- 40 & Brown \\
\hline P- 41 & Dark Brown \\
\hline P- 42 & Black \\
\hline P- 43 & Pink \\
\hline P- 44 & Red \\
\hline
\end{tabular}

\subsection{Sample and Reagent Treatment Method}

Mention the statistical details, the number of samples used, statistical tools/software used/ SD/level of significance, repeatability etc.

1) 5 Semi-permanent pigment samples were put into aseptic case in accordance with sterility test method of Korean Pharmacopoeia general analytical method[Fig. 1-5].
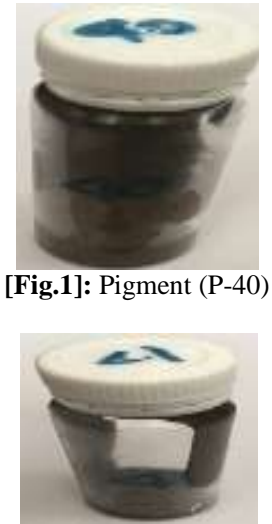

[Fig. 2]: Pigment (P-41)

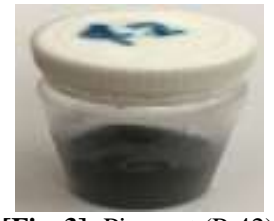

[Fig. 3]: Pigment (P-42)

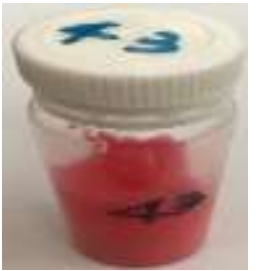

[Fig. 4]: Pigment (P-43)

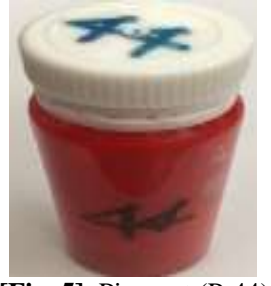

[Fig. 5]: Pigment (P-44)
2) Sampling

For sampling of 5 semi-permanent products, the sample shaken for mixing before sampling and collected using sterile spatula.

3) Standard solution of sample

Excluding the solution marked with rate and purity, the experiment used acid for heavy metal testing, for semiconductor and special level (GR or ACS level).

\subsection{Experiment Measurement Principle2}

\subsubsection{Inductively Coupled Plasma- Atomic Emission Spectroscopy (ICP-AES)}

The luminous ray and luminous intensity emitted when excited atom in condition of $6,000 \sim 8,000 \mathrm{~K}$ is in transition to ground state by injecting used sample to argon plasma formed by highfrequency induction coil.

2.3.2 Inductively Coupled Plasma - Mass Spectrometry (LCICP-MS)

By spraying sample on plasma, and injecting it with quadrupole mass spectrometer after desolvation, ionization and atomization, the heavy metal was analyzed.

\subsection{Experiment Analysis Equipment}

2.4.1 ICP/wnd(Perkinelmer, Optima 5300 DV) was used in heavy metal analysis in this experiment

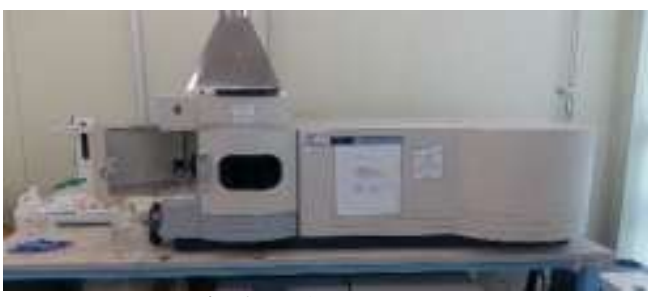

Fig.6: Optima 5300 DV

\section{Results}

\subsection{Experiment Result of Barium}

Restriction standard of antimony is less than $2 \mathrm{mg} / \mathrm{kg}$. Among samples with self-check number, no.42 sample had the highest antimony content of $43.3 \mathrm{mg} / \mathrm{kg}$ [Table 4].

Table 4: The content of antimony (Sb) (Standard: below $2 \mathrm{mg} / \mathrm{kg}$ )

\begin{tabular}{|l|l|}
\hline Pigment Number & $\mathrm{Sb}(\mathrm{mg} / \mathrm{kg})$ \\
\hline P- 40 & $<10$ \\
\hline P- 41 & $<10$ \\
\hline P- 42 & 43.3 \\
\hline P- 43 & $<10$ \\
\hline P- 44 & $<10$ \\
\hline
\end{tabular}

\subsection{Experiment Result of Cobalt}

Restriction standard of cobalt is less than $25 \mathrm{mg} / \mathrm{kg}$. Among samples with self-check number, no. 41 sample had the highest cobalt content of $30.2 \mathrm{mg} / \mathrm{kg}$ which exceeded standard thus, inappropriate[Table 5].

Table 5: The content of cobalt (Co)(Standard : Below $25 \mathrm{mg} / \mathrm{kg}$ )

\begin{tabular}{|l|l|}
\hline Pigment Number & $\mathrm{Co}(\mathrm{mg} / \mathrm{kg})$ \\
\hline P- 40 & $<10$ \\
\hline P- 41 & 30.2 \\
\hline
\end{tabular}




\begin{tabular}{|l|l|}
\hline P- 42 & $<10$ \\
\hline P- 43 & $<10$ \\
\hline P- 44 & $<10$ \\
\hline
\end{tabular}

\begin{tabular}{|l|l|}
\hline P- 43 & $<10$ \\
\hline P- 44 & $<10$ \\
\hline
\end{tabular}

\subsection{Experiment Result of Copper}

\subsection{Experiment Result of Tin}

Restriction standard of copper is less than $25 \mathrm{mg} / \mathrm{kg}$. Among samples with self-check number, no. 40's cobalt content was $12.3 \mathrm{mg} / \mathrm{kg}$, and no. 41 was $10.6 \mathrm{mg} / \mathrm{kg}$ which exceeded $10 \mathrm{mg} / \mathrm{kg}$, but it was lower than restriction standard $(25 \mathrm{mg} / \mathrm{kg})$ [Table 7].

Table 7: The content of copper $(\mathrm{Cu})($ Standard : Below $25 \mathrm{mg} / \mathrm{kg})$

\begin{tabular}{|l|l|}
\hline Pigment Number & $\mathrm{Cu}(\mathrm{mg} / \mathrm{kg})$ \\
\hline P- 40 & 12.3 \\
\hline P- 41 & 10.6 \\
\hline P- 42 & $<10$ \\
\hline P- 43 & $<10$ \\
\hline P- 44 & $<10$ \\
\hline
\end{tabular}

\subsection{Experiment Result of Lead}

Restriction standard of lead is less than $2 \mathrm{mg} / \mathrm{kg}$. Among samples with self-check number, no. 40 's lead content was $12.7 \mathrm{mg} / \mathrm{kg}$ and no. 41 was $13.4 \mathrm{mg} / \mathrm{kg}$ which confirmed its abnormal content over 6 times [Table 8].

Table 8: The content of lead $(\mathrm{Pb})($ Standard : Below $2 \mathrm{mg} / \mathrm{kg})$

\begin{tabular}{|l|l|}
\hline Pigment Number & $\mathrm{Pb}(\mathrm{mg} / \mathrm{kg})$ \\
\hline $\mathrm{P}-40$ & 12.7 \\
\hline $\mathrm{P}-41$ & 13.4 \\
\hline $\mathrm{P}-42$ & $<10$ \\
\hline $\mathrm{P}-43$ & $<10$ \\
\hline $\mathrm{P}-44$ & $<10$ \\
\hline
\end{tabular}

\subsection{Experiment Result of Zinc}

Restriction standard of zinc is less than $50 \mathrm{mg} / \mathrm{kg}$. Among samples with self-check number, no. 41 's zinc content was $201 \mathrm{mg} / \mathrm{kg}$ and no. 40 was $173 \mathrm{mg} / \mathrm{kg}$ which is much higher than restirction standard $(50 \mathrm{mg} / \mathrm{kg})$, while zinc content of no. 42 was $14 \mathrm{mg} / \mathrm{kg}$ which was much less than standard indicating comparatively safe result[Table 9].

Table 9: The content of zinc ( $\mathrm{Zn})($ Standard : Below $50 \mathrm{mg} / \mathrm{kg})$

\begin{tabular}{|l|l|}
\hline Pigment Number & $\mathrm{Zn}(\mathrm{mg} / \mathrm{kg})$ \\
\hline P- 40 & 173 \\
\hline P- 41 & 201 \\
\hline P- 42 & 14 \\
\hline P- 43 & $<10$ \\
\hline P- 44 & $<10$ \\
\hline
\end{tabular}

\subsection{Experiment Result of Barium}

Restriction standard of barium is less than $50 \mathrm{mg} / \mathrm{kg}$. Among samples with self-check number, barium content of no. 40 was $25.1 \mathrm{mg} / \mathrm{kg}$ and no. 41 was $29.4 \mathrm{mg} / \mathrm{kg}$. However, there was no sample that had exceeded barium standard[Table 10].

Table 10: The content of barium (Ba)(Standard : Below $50 \mathrm{mg} / \mathrm{kg}$ )

\begin{tabular}{|l|l|}
\hline Pigment Number & $\mathrm{Ba}(\mathrm{mg} / \mathrm{kg})$ \\
\hline P- 40 & 25.1 \\
\hline P- 41 & 29.4 \\
\hline P- 42 & $<10$ \\
\hline
\end{tabular}

Restriction standard of tin is less than $50 \mathrm{mg} / \mathrm{kg}$. Among samples with self-check number, tin content of all samples were less than $10(\mathrm{mg} / \mathrm{kg})$ which indicated comparatively safe result[Table 11].

Table 11: The content of tin (Sn)

\begin{tabular}{|l|l|}
\hline Pigment Number & Sn $(\mathrm{mg} / \mathrm{kg})$ \\
\hline P- 40 & $<10$ \\
\hline P- 41 & $<10$ \\
\hline P- 42 & $<10$ \\
\hline P- 43 & $<10$ \\
\hline P- 44 & $<10$ \\
\hline
\end{tabular}

\section{Discussion}

This study conducted analysis on heavy metal and other metals of pigment used in cosmetic tattoo, and the discussion about the result is as follows. As for the result of heavy metal content of antimony, its restriction standard is less than $2 \mathrm{mg} / \mathrm{kg}$.

Antimony content of sample no. 42 with self-check number is 43.3 $\mathrm{mg} / \mathrm{kg}$ which is 40 times as much as the standard. Antimony is a chemical and toxic material which affects gastric mucous membrane once exposed to human body and causes consistent vomiting, abdominal cramping, diarrhea, cardio toxicity, liver damage and chronic respiratory disease [6,7]. Thus, it requires caution when using.

As for the result of heavy metal content of cobalt, its restriction standard is less than $25 \mathrm{mg} / \mathrm{kg}$. Cobalt content of sample no. 41 with self-check number is $30.2 \mathrm{mg} / \mathrm{kg}$ which exceeded standard. This is because cobalts are used much to make brown colors. Cobalt is the major material causing allergic reaction with slightest concentration, which could led to serious health risks [7]. Thus, cobalt concentration must be strictly observed, and administration of relevant authority must be done.

As for the result of heavy metal content of copper, its restriction standard is less than $25 \mathrm{mg} / \mathrm{kg}$. Copper content of sample no. 40 with self-check number is $12.3 \mathrm{mg} / \mathrm{kg}$ and no. 41 is $10.6 \mathrm{mg} / \mathrm{kg}$ which both exceed $10 \mathrm{mg} / \mathrm{kg}$ but lower than restriction standard. This material is used mainly to make brown color. However, copper has harmful influence on human body even in low concentration, and excessive exposure could affect Alzheimer's disease, Parkinson disease, muscular atrophy [6].

As for the result of heavy metal content of lead, its restriction standard is less than $2 \mathrm{mg} / \mathrm{kg}$. Lead content of sample no. 40 and 41 with self-check number are $12.7 \mathrm{mg} / \mathrm{kg}$ and $13.4 \mathrm{mg} / \mathrm{kg}$ each which are 6 times higher than standard. Once human body is exposed to low concentration of lead, it could cause degradation of learning ability, hearing ability, permanent nerve damage, and anemia or mental derangement from lead poisoning [9,10]. Lead remains in body after tattooing, so those who make and use the pigment must be cautious.

As for the result of heavy metal content of zinc, its restriction standard is less than $50 \mathrm{mg} / \mathrm{kg}$. Zinc content of sample no. 41 and 40 with self-check number are $201 \mathrm{mg} / \mathrm{kg}$ and $173 \mathrm{mg} / \mathrm{kg}$ each which are 4 and 3 times higher than standard. Sample no. 41 had zinc content of $14 \mathrm{mg} / \mathrm{kg}$. Zinc is mostly used in making brown and black color, so comparatively low content was detected in pink and blood color for lip color. Zinc could cause loss of appetite, weight loss, depression, muscle weakness, ankylosis and growth retardation, so it requires caution for cosmetic tattooing $[8,11]$. 
As for the result of heavy metal content of barium, its restriction standard is less than $50 \mathrm{mg} / \mathrm{kg}$. Barium content of sample no. 40 and no. 41 with self-check number are $25.1 \mathrm{mg} / \mathrm{kg}$ and $29.4 \mathrm{mg} / \mathrm{kg}$ each. However there was no sample that exceeded restriction standard.

As for the result of heavy metal content of tin, its restriction standard is less than $50 \mathrm{mg} / \mathrm{kg}$. Tin content of all samples with selfcheck number did not exceed restriction standard. However, even a slightest amount of heavy metal can cause liver disease or pose potential damages to skin, tumor, cancer, respiratory and cardiovascular system $[12,13]$. Thus, cosmetic tattooing must be followed by recognition about all risks.

\section{Conclusion}

As a result of examining the contents of heavy metals in dyes and pigments used in cosmetic tattoo products, it was found that the total of 5products exceeded the reference value and found to be unsuitable for safety standards.Heavy metals contained in pigment injected to skin remain in human body for long time. Even low concentration of heavy metal could be risky to human body, but as most of the pigments are used in small amount, it is impossible to distinguish all components of pigment mixture due to limited detection of concentration in accordance with certain color and function. Thus, it requires marking of detailed compound ingredient and guidelines. There is a need for micro content analysis using precise measuring tool in the future. Certain pigment components could cause various symptoms such as allergic reaction, dermatitis, contact dermatitis. Thus, there must be a development of proper technology to conduct precise component detection of pigment.

\section{References}

[1] H, G, Hall., D, Griffiths \& L, G, McKenna. (2015). Complementary and Alternative Medicine: Interaction and Communication Between Midwives and Women. Women and Birth, 28(2), 137-14.DOI: 10.1016/j.wombi.2014.12.003. Epub 2015 Jan 2.

[2] S, M,Wenzel., J. Welzel, C,Hafner., M,Landthaler\& W, Bäumler. (2010). Permanent make-up colorants may cause severe skin reactions. Contact Dermatitis, 63(4), 223-227. DOI:10.1111/j.1600-0536.2010.01799.x.

[3] N. Kluger\& V. Koljonen, (2012).Tattoos, inks, and cancer.The lancet Oncology, 13(4), 161-168. DOI: /10.1016/S14702045(11)70340-0

[4] Schreiver, I., Hutzler, C., Andree, S., Laux, P., \&Luch, A. (2016). Identification and hazard prediction of tattoo pigments by means of pyrolysis - gas chromatography/mass spectrometry. Archives of toxicology, 90(7), 1639-1650.

[5] Sanghavi, Swapnil.,Dongre, Atul., Khopkar, \&Uday. (2013). Tattoo reactions-An epidemic on the surge: A report of 3 cases. Indian Journal of Dermatology, Venereology and Leprology; Vellore, 79(2), 231-234.DOI:org.library.hanseo.ac.kr:8000/10.4103/03786323.107644

[6] Rafiei, Behrouz.,Khodaei, Azam, Sadat., Khodabakhsh, Saeid. Hashemi, Mahdi \&Nejad, Masoumeh Bakhtiari.(2010). Contamination Assessment of Lead, Zinc, Copper, Cadmium, Arsenic and Antimony in Ahangaran Mine Soils, Malayer, West of Iran. Soil \& Sediment Contamination, 19(5),573-586.DOI: 10.1080/15320383.2010.499921.

[7] Shi, Zunji., Cao, Zhan., Qin, Dong; Zhu, Wentao., Wang, Qian; Li, Mingshun\& Wang, Gejiao. (2013). Correlation Models between Environmental Factors and Bacterial Resistance to Antimony and Copper. Accelerating the Publication of Ppeer-Reviewed Science, 8(10), 1-11. DOI: 10.1371/journal.pone.0078533.

[8] Christa De Cuyper. (2008). Permanent makeup: indications and complications. Clinics in Dermatology, 26(1), 30-34.DOI: 10.1016/j.clindermatol.2007.10.009.

[9] Schreiver, C. Hutzler, S, Andree, P. Laux\& A. Luch, (2016) Identification and hazard prediction of tattoo pigments by means of pyrolysis-gas chromatography/mass spectrometry. Archives of Toxicology, 90(7), 1639-1650.DOI: 10.1007/s00204-016-1739-2

[10] Niti, Khunger., Anupama Molpariya1., \& Arjun Khunger. (2015).
Complications of tattoos and tattoo removal: Stop and think before

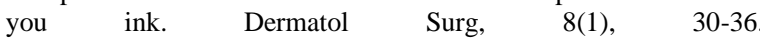
DOI:org.library.hanseo.ac.kr:8000/10.4103/0974-2077.155072

[11] Saijun Zhou., Ning Li., Bozhi Ren \& Peng Zhang. (2017). Release Law of Sb, As, and $\mathrm{Hg}$ in Antimony Smelting Slag Under Simulated Acid Rain. Polish Journal of Environmental Studies, 26(3), 925-933.DOI: 10.15244/pjoes/65470.

[12] Niti,Khunger., AnupamaMolpariya\& Arjun Khunger. (2015). Complications of tattoos and tattoo removal: Stop and think before you ink. Journal of Cutaneous and Aesthetic Surgery, 8(1), 30-36. DOI: 10.4103/0974-2077.155072

[13] A,Messahel\& B, Musgrove. (2009). Infective complications of tattooing and skin piercing. Journal of Infection and Public Health, 2(1), 7-13.DOI: 10.1016/j.jiph.2009.01.006. 